\section{Even Mr. K Has to Bow to U.S. Farmers}

"Farming is everybody's business. It's the biggest business in America - and the only one to which even Khrushchev tips his hat.

"It's a $\$ 38$ billion-a-year industry that affects our taxes, our foreign policy, our housewives' budgets and our eating habits."

So says Kenneth Scheibel, who for 12 years has covered farm news from Washington for the Gannett papers and is now starting a weekly column, "Washington Farm Beat," for North American NewsFaper Alliance.

Our readers will wish to watch their daily newspaper for this NANA 700word weekly farm column issued for Monday publication.

\section{(Continued from Previous Page)}

diseases than one under stress. Any management practice which lowers the vigor of the grass will make it more vulnerable to mite infestation.

\section{Telltale Tufted Look}

A mite-infested bermuda turf will develop a tufted growth with numerous small leaf blades. Brown spots will be evident after mowing. Chemical control of the mite with diazinon can be accomplished if applied when the mites are first noticed. Delaying treatment until damage is severe results in a weakened stand of grass and recovery will be slow. If mites are present, extra attention should be given to fertilization, watering and mowing in order to create a more favorable environment for recovery of the lawn area.

Winter dormancy of bermudagrass is one of the main objections to its use as a turf grass. This thermo-dormancy is offset by overseeding the lawn area with one of the many cool season grasses in late fall. Tests are being made to determine the adaptability of bents, bluegrass, fescues and others, compared to the traditional standby, annual ryegrass, for overseeding.

Overseeding bermudagrass in early fall prior to its dormant period has created a problem of preventing further growth after it has been overseeded with a cool season grass. Growth retardants are being used effectively on bermuda prior to seeding to control its growth during this warm period.

Hybrid strains and selections of bermuda grass are being tested for their adaptability to withstand our climatic conditions in the Southwest. They are also being evaluated for their texture and use in golf courses and home yards.

\title{
Agriculture and the Common Market
}

"All parents tell their children about the piggies," says Dr. Conrad F. Joyner, University of Arizona associate professor of government, "but dilemmas arising out of the creation of the European Common Market (ECM) make it possible to tell the story in a new way."

This little piggy went to the Common Market.

This little piggy stayed home in Iowa.

This little piggy wished he were roast beef.

This little piggy didn't know what he was.

This little piggy cried "wee, wee, wee, I can't find my home."

"We find in the world today the paradox of agricultural abundance in some areas in contrast to over-all scarcity," says Dr. Joyner. Technical advances and fertile land make some areas more productive than others yet the rising birth rate and lower infant mortality rate have caused a scarcity of food.

Tariffs and other barriers discourage distribution from the more productive areas to those less fortunate.

The traditional economic solution to these problems is a free world market in which each country produces what it is best suited to, imports what it needs and exports its surplus.

In the long run (theoretically) everything would balance out.

The European Common Market is supposedly moving towards this type of free world market.

Differences between the agricultural situation in the Common Market and that in the United States will create dilemmas. Some of the differences he points out, are that the United States farmer is more ef ficient, that the Common Market must import some of its agricultural products and that despite aids, farmers in Common Market countries have a lower income than those here.

In the European Common Market there are 180 million acres under agricultural production; in the United States there are 300 million acres.

In the ECM there are 900 million farms; in the United States there are 3.7 million farms. We have abandoned the $12,15,17$ and 18 acre farms that still exist in abundance in Europe, Dr. Joyner notes.

In the ECM there are 12.5 million male farm workers; in the United States there are only half that many.

The goal of the ECM is to solve some of the problems inherent in the European agricultural situation.

Editor's Note: This summary of Dr. Joyner's talk, before the League of Women Voters' foreign economic policy workshop here, was written by Susan Szekely of The Tucson Daily Citizen staff.
In moving towards a solution these aims have been stated:

1. To attempt to balance supply and demand, not only within the market but also as it relates to the rest of the world.

2. To provide a fair income to the farmer.

3. To stabilize agricultural markets by providing a price the farmer can depend upon.

4. To insure a fair deal to the con: sumer.

How do these aims affect us? The United States sells \$5 billion worth of products to the Common Market. Of these, $\$ 1.2$ billion are agricultural producis, more specifically grains, pork, poultry and eggs. We cannot lose this trade without drastic effect, says Dr. Joyner.

Therefore, he feels, we must maintain bargaining with the Common Market. If we are not successful, we will have serious problems for our own agriculture.

Dr. Joyner concludes that the United States may have been instrumental in creating something that it does not know how to handle.

\section{Arizona Farm Income $\$ 5121 / 2$ Million in '62}

Arizona farmers received a record income of $\$ 512,588,000$ in cash receipts last year, 9 per cent above the 1961 figure.

The U.S. Department of Agriculture said crops accounted for most of the receipts with a total return of $\$ 324,688,000$, up 12 per cent from 1961.

Up 3 per cent at $\$ 182,575,000$ were cash receipts from livestock and livestock products

Cotton lint and cottonseed earned more than half the crop income. Government payments to Arizona farmers in 1962 totaled $\$ 5,325,000$, an increase of $\$ 40$, 000 from the preceding year.

The government payments are not included among cash receipts totals.

El ganado vacuno de carne debe seleccionarse de un tipo que alcance pronto su edad adulta, recio, y, que, bajo condiciones adecuadas, a la edad de los 12 a 18 meses llegue a pesar de 320 a $450 \mathrm{~kg}$. Conviene escoger una raza que se adapte mejor a las condiciones locales. La preferencia personal debe ser una consideración muy importante al escoger una raza.-TIERRA

Fishes in ditches are a help to farmers in Arizona's Buckeye Valley where a tropical species, tilapia, were planted in canals last year The fish feed on warm water algae which slow water movement. The state has now planted 2,000 tilapia in the Roosevelt Irrigation District.

May-June 1963 Page 6 